\title{
EKOSISTEM PESANTRENPRENEUR BERBASIS PENGEMBANGAN POTENSI LOKAL
}

\section{PESANTRENPRENEUR ECOSYSTEM BASED ON LOCAL POTENTIAL DEVELOPMENT}

\author{
Fauzan Adhim', Ta'rif ${ }^{2}$ \\ ${ }^{1}$ Institut Agama Islam Al Falah Assunniyah Kencong Jember \\ ${ }^{2}$ Puslitbang Pendidikan Agama dan Keagamaan, Badan Litbang dan Diklat, Kementerian Agama RI \\ email: fauzanazizah19@gmail.com,ta75rif@gmail.com
}

Naskah Diterima: 10 Agustus 2021; Direvisi: 13 Agustsu 2021; Disetujui: 18 Agustus 2021

\begin{abstract}
During this, managing the economy at Islamic boarding schools has only functioned as a supporting system. The business cycle that has been carried out has not yet reached the maximum utilization of vital resources. Its economic potential has not been appropriately explored and sustainably. The two Islamic boarding schools that are the locus of this research have been accelerated. Using a qualitative approach, this study explored the development of human resources, optimization of production processes, and good marketing strategies at Pesantrenpreneur. The data was collected through interviews, discussions, and observations. Data analysis used a cross-case analysis technique that describe the same characteristics from the two research locations. The study's findings include: first, the strategy of developing human resources for pesantren-preneur includes Internalization of values, human resource management, and support systems. Second, the production process of the entrepreneurial boarding school starts from potential analysis, supplier selection, product differentiation to innovation and control. Third, the marketing approach uses an open marketing system and a closed system.
\end{abstract}

Keywords: HR Development; Marketing; Pesantrenprenuer; Production Chain

\begin{abstract}
Abstrak
Praktik pengelolaan ekonomi pondok pesantren selama ini hanya berfungsi sebagai supporting system. Siklus bisnis yang dijalankan belum sampai pada pemanfaatan sumber daya vital secara maksimal. Potensi ekonominya belum dieksplor secara baik dan berkelanjutan. Dua pondok pesantren yang menjadi lokus penelitian ini telah melakukan akselerasi ekonomi dengan baik. Penelitian ini maksudkan untuk mengeksplorasi pengembangan sumber daya manusia kompeten, Optimasi proses produksi dengan standar yang terukur, dan Penggunaan strategi dan pendekatan marketing yang baik. Penelitian ini menggunakan pendekatan kualitatif. Teknik pengumpulan data melalui wawancara, diskusi dan observasi. Analisis data yang digunakan dengan teknik analisis lintas kasus yang mengabstraksi karakteristik yang sama dari dua lokasi penelitian. Temuan penelitian ini meliputi: pertama, strategi pengembangan sumber daya manusia pesantrenprenuer meliputi: Internalisasi nilai, Manajemen sumber daya manusia, dan support system. Kedua, proses produksi pesantrenprenuer dimulai dari analisa potensi, pemilihan supplier, deferensiasi produk, hingga inovasi dan pengendalian. Ketiga, Pendekatan marketing menggunakan open system marketing dan closed system.
\end{abstract}

Kata kunci: Marketing; Pengembangan SDM; Pesantrenprenuer; Rantai Produksi 


\section{PENDAHULUAN}

Pondok pesantren (ponpes) memiliki jejak historis yang panjang dalam melakukan pemberdayaan masyarakat (Nafik, 2018). Beberapa aspek pemberdayaan yang senantiasa dilakukan oleh ponpes adalah bidang SDM, sosial-kegamaan dan ekonomi. Munculnya Nahdlatut Tujjar (NT) pada tahun 1918 yang diinisiasi oleh tradisionalis pesantren merupakan bukti sejarah bahwa ponpes sejak awal memang memiliki concern terhadap ekonomi umat (Fikri, 2017). NT juga dikenal sebagai salah satu ijtihad ekonomi keummatan para muassis NU dan ponpes yang memiliki peran strategis dalam kemandirian ekonomi umat.

Menurut Fauzan, urgensi dan peran strategis ponpes dalam konteks pengembangan ekonomi didasari pada enam faktor: [1] Kamajuan ekonomi ponpes dapat menjadi stimulus finansial kegiatan dan pengembangan ponpes, [2] Penggerak pemberdayaan ekonomi masyarakat sekitar, [3] Menjadi laboraturium ekonomi kerakyatan berbasis syariah, [4] Memacu jiwa enterpreneurship santri, [5] Mendorong tingkat pertumbuhan ekonomi mikro-menengah dan [6] Menciptakan kemandirian lembaga dan mengurangi ketergantungan finansial eksternal (Fauzan Adhim, 2020).

Beberapa ponpes telah mampu melakukan akselerasi di bidang ekonomi. Termasuk dalam konteks ini adalah beberapa ponpes yang mampu melakukan pemanfaatan terhadap potensi lokal. Menurut Churiyah, Potensi lokal dalam wirausaha meliputi: [1] Sumber daya manusia, [2] Sumber daya alam, [3] Sumber daya budaya, dan [4] Sumber daya teknologi (Madziyatul Churiyah, 2015). Anggota OPOP sekaligus pegiat ekonomi ponpes di Kabupaten Jember, Imam Bukhori, mengatakan bahwa potensi lokal ponpes yang dapat diakselerasi menjadi sebuah Economic Potential adalah pertanian, peternakan, perbengkelan, sembako, perdagangan dan jasa (Wawancara dengan Imam Bukhori, 2 Nopember 2020 ). Hasil riset dari Nafik juga semakin mempertegas potensi lokal yang dapat digarap oleh ponpes adalah dalam bidang: 1) perdagangan, yaitu toko sembako, es batu, pom mini, toko buku, dll.; 2) industri pengolahan, yaitu air mineral, konveksi, produksi sandal jepit, shampoo, dll.; 3) pertanian, meliputi tebu, padi, kedelai, jagung, dll.; 4) peternakan, yaitu ayam petelur, ayam potong, kambing, sapi, dll.; 5) perkebukan yaitu: sengon, kopi, kelapa, the, dll.; dan 6) jasa, yaitu travel haji/umroh, travel domestik, klinik, laundry, dll. (Muhammad Nafik Hadi, 109).

Ponpes Ihya'ussunnah dan Madinatul Ulum merupakan lembaga pendidikan keagamaan yang memiliki beberapa terobosan dalam bidang pengembangan ekonomi ponpes. Namun demikian, kedua ponpes ini memiliki corak pengembangan ekonomi yang berbeda. Pondok Ihya'ussunnah mengembangan ekonomi ponpes melalui produksi kopi. Melalui industri pengolahan kopi ini, ponpes Ihya'ussunnah mampu menggratiskan seluruh santrinya. Mulai dari biaya pendidikan hingga biaya living cost. Usaha ini dikelola langsung oleh siswa/siswi SMK Pertanian milik ponpes.

Ponpes Ihya'ussunnah berada pada wilayah pusat perkebunan kopi. Komoditas kopi ini selanjutnya dimanfaatkan sebagai salah satu sektor pengembangan ekonomi masyarakat dan pesantren. Sumber daya yang melimpah membuat produksi kopi ini menjadi potensi besar. Namun demikian, diperlukan instrumen pengelolaan usaha yang memadai. Berdirinya SMK Pertanian dan perkebunan di pesantren ini sebagai upaya untuk menopang SDM lokal. Menurut Imam Bukhori, SDM pengelola diperusahaan ini berasal dari dua kalangan, yaitu SDM Lokal dari SMK dan tenaga pendamping ahli yang didatangankan dari pergutuan tinggi di kabupaten Jember (Wawancar dengan Imam Bukhori, 2 Nopember 2020). Dari sisi produksi, Kopi BIKLA (Brand; Barokah Ibrahimy Kopi Lereng Argopuro) dilengkapi dengan Standar operasional prosedur (SOP) dan pendampingan intens dari kepala bagian produksi. Kedunya sebagai sistem kendali atas keseluruhan proses produksi. Sementara itu, pada aspek marketing, BIKLA telah melakukan adposi sistem pemasaran Multi Level Marketing (MLM) sekaligus memanfaatkan kekuatan alumni dan simpatisan sebagai ujung tombak pemasaran produk. 
Sementara itu, Ponpes Madinatul Ulum di wilayah pinggiran kota. Sebagian besar di wilayah ini, memiliki potensi pada sektor pertanian dan peternakan. Madinatul Ulum memiliki fokus pengembangan usaha pada sektor peternakan. Pilihan fokus ini ditentukan karena besarnya kebutuhan wilayah Jember secara umum terhadap suplai daging ayam. Dalam rangka menopang kebutuhan besar dan menjamin keberlanjutan produksi peternakan tersebut, Madinatul Ulum melakukan peningkatan kapasitasnya dengan tiga strategi utama; yaitu, Pengembangan teknologi produksi, peningkatan keterampilan SDM dan perluasan pasar ritel dan kemitraan (Wawancara dengan KH. Lutif Ahmad, 5 Nopember 2020). Gambaran sederhana dari wirausaha kedua ponpes tersebut dapat dilihat pada Tabel 1.

Tabel 1. Gambaran usaha pondok pesantren

\begin{tabular}{lll}
\hline \multicolumn{1}{c}{ Nama Pondok } & \multicolumn{1}{c}{ Fokus Usaha } & \multicolumn{1}{c}{ Keunggulan } \\
\hline \multirow{3}{*}{ Madinatul Ulum } & \multirow{2}{*}{ Peternakan } & Teknologi \\
& & SDM \\
& & Produksi \\
\hline \multirow{3}{*}{ Ihya'ussunnah } & \multirow{2}{*}{ Produksi Kopi } & SDM \\
& & Produksi \\
& & Marekting \\
\hline
\end{tabular}

Sumber: Elaborasi Hasil Wawancara

Keberhasilan dua ponpes tersebut, terutama dalam membangun keunggulan, improvisasi manajemen dan mengembangkan teknologi merupakan kunci dibalik suksesnya pengembangan ekonomi yang dijalankan. Tabel 1 memberikan gambaran tentang beberapa elemen atau unsur wirausaha ponpes yang dikembangan. Kompleksitas stimulus dan sistem yang dijalankannya menjadikan dua model wirausaha ini dapat eksis dan berkembangan secara baik. Atas dasar ini, maka peneliti menggali best practice pendidikan enterpreneurship yang dikembangan di dua ponpes ini dengan berfokus pada tiga hal: [1] Strategi pengembangan hard skill dan soft skill SDM, [2] Aspek rantai produksi atau sistem produksi dari dua model usaha ponpes, dan [3] Marketing, yaitu strategi dan inovasi pemasaran yang dikembangkan oleh dua ponpes tersebut. Tiga hal ini sekaligus menjadi keunggulan dasar dari wirausaha yang dikembangakn oleh ponpes Madinatul Ulum dan ponpes Ihya'ussunnah.

\section{KAJIAN TEORI}

\section{Ekosistem Pesantrenpreneur}

Penggunaan istilah pesantrenpreneur memang belum familiar dibeberapa kalangan. Istilah ini pertama kali marak digunakan pada tahun 2018 saat menjadi salah satu program unggulan provinsi Jawa Timur dalam bidang pengembangan ekonomi berbasis pesantren (Tim OPOP Jatim, 2019). Pesantrenpreneur sendiri merupakan gabungan antara "pesantren" dan "enterpreneur". Gabungan dua termenologi ini "Pesantrenpreneur" memiliki pengertian sebuah institusi atau lembaga ponpes yang menjalankan peran strategisnya dalam bidang wirausaha melalui pendekatanpendekatan yang inovatif, profesional dan produktif (Tim OPOP Jatim, 2019). Sementara itu, ekosistem bermakna sebuah gabungan dan rangkaian dari berbagai sistem atau entitas.

Berdasarkan ini dapat difahami bahwa ekosistem pesantrenpreneur bermakna beberapa rangkaian atau sistem yang menjadi unsur penting dalam wirausaha ponpes. Ekosistem pesantrenpreneur sendiri memiliki empat unsur penting, yaitu kelembagaan, SDM, produksi dan marketing. Hal ini selarasa dengan teori Isenberg, dimana ia menjelaskan bahwa ekosistem enterpreneurship itu memiliki 6 sistem, yaitu Policy, market, finance, human capital, culture, dan support (Gambar 1) (Armando, 2020).

Teori ini menggambarkan tentang kompleksitas sistem wirausaha yang harus dijalankan oleh seseorang atau lembaga. Menurut Colin, teori ini menawarkan perspektif baru mengenai wajah wirausaha dengan menjadikan beragam sistem menjadi 
satu kesatuan yang sama-sama penting (Colin, 2014). Kendatipun masih dilakukan uji coba,
Colin menambahkan kondisi geografis sebagai bagian dari ekosistem ini.

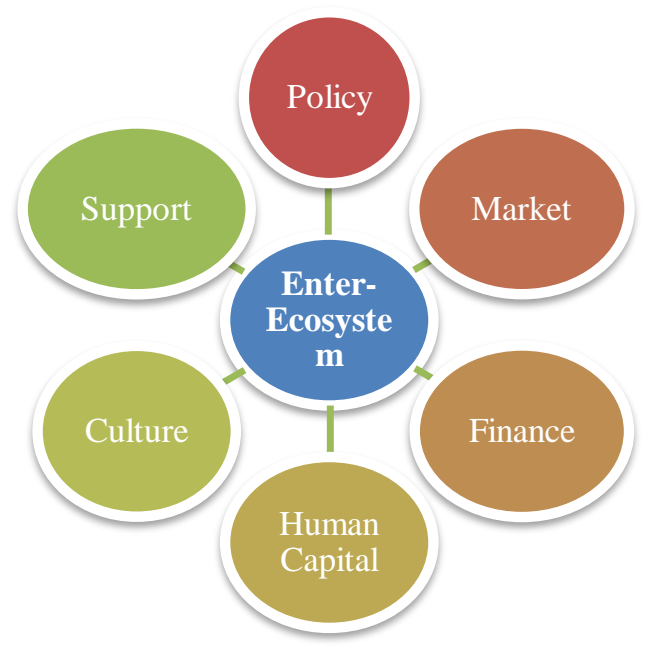

Gambar 1. Teori Enterpreneurship Ecosystem

Sumber: Colin, Entrepreneurial Ecosystems and Growth Oriented Entrepreneurship, hlm. 06

\section{Potensi Lokal}

Urgensi pengembangan potensi lokal untuk kepentingan pemanfaatan sumber daya merupakan sebuah keniscayaan (Dayat, 2019). Menurut Soleh, Potensi lokal sendiri merupakan sebuah kemampuan, kekuatan yang berada pada sebuah lokus tertentu (Soleh, 2017). Potensi ini dapat berbentuk fisik dan non fisik. Potensi fisik meliputi, kondisi geografis, SDM dan fasilitas lainnya. sementara potensi non fisik dapat berupa kebudayaan, informasi, dinamika kultur dan lainnya. Pendapat Soleh ini selaras dengan pendapat Churiyah, dimana ia menjelaskan bahwa sumber daya lokal atau potensi lokal meliputi: Sumber daya alam, SDM, kebudayaan dan teknologi. Unsur potensi lokal ini dapat digambarkan pada Gambar 2.

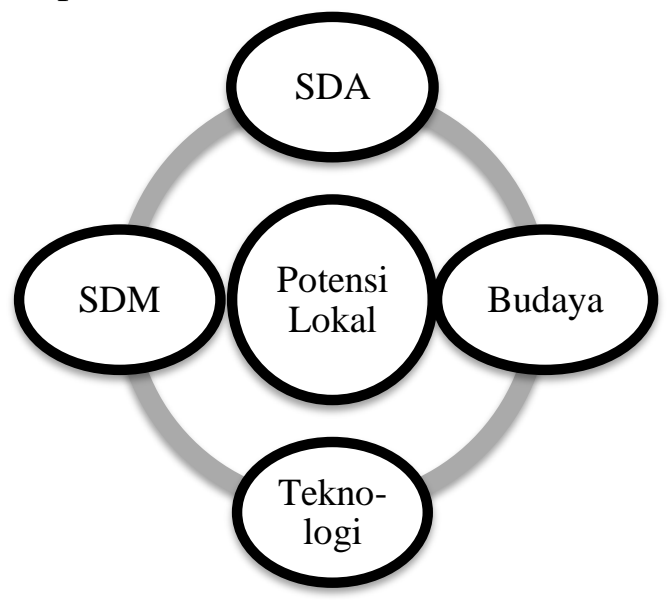

Gambar 2. Unsur potensi lokal

Sumber: Formulasi Konsep Peneliti

\section{Strategi Pengembangan SDM}

Sebagai salah satu unsur penting dalam sebuah organisasi atau perusahaan, SDM senantiasa menjadi kajian menarik untuk didiskusikan. Dalam konteks ini, sebagai bahan analisa untuk mengurai dan menggali strategi pengembangan SDM yang diterapkan oleh dua unit wirausaha ponpes, peneliti menggunakan teori Guest. Sebagaimana di kutip oleh Renata, bahwa strategi pengembangan SDM atau dikenal dengan strategic human resources management (SHRM) berpijak pada tiga dimensi, yaitu Competencies, Motivation and effort dan Opportunities to contribute (Renata, 2017). Tiga dimensi dan langkah praktis 
pengembangan SDM ini dapat dilihat pada Tabel 2.

Tabel 2. Teori Dimensi SHRM

Dimensi

\section{Kompetensi}

Motivasi dan usaha

Kesempatan untuk

berkontribusi

\section{Praktik MSDM}

Rekrutmen dan Seleksi; pelatihan, pengembangan dan pendidikan.

Evaluasi kinerja, penghargaan, insentif, tunjangan, promosi dan pengembangan karir, dan keamanan kerja.

Desain alur kerja, tim kerja, kebijakan keterlibatan karyawan, berbagi informasi dan sistem formal pengaduan dan klaim.

Sumber: Renata Peregrino de Brito, The Relationship Between Human Resource Management and Organizational Performance, hlm. 94

\section{Rantai Produksi}

Menurut Ahyari, sebagaimana dikutip oleh Damar menjelaskan bahwa Proses produksi adalah suatu cara atau metode serta teknik yang dapat menambah kegunaan suatu barang dan jasa dengan melakukan optimasi pada faktor-faktor produksi yang ada. Proses ini dimulai dari input atau supplay hingga pengendalian produksi (Damar, 2018). Sementara itu, dipandang dari sisi tipenya,
Yamit menjelaskan tentang proses produksi dapat dibedakan menjadi tiga: [1] Proses produksi terus menerus, [2] Produksi terputus atau intermitten process. [3] Proses produksi campuran (Damar, 2018). Tiga tipe ini menjadi sebuah rangkaian produksi yang terdiri dari empat tahap, yaitu supplay, proses atau produksi, pengendalian dan pengembangan. Pendapat Yamit ini dapat dilihat pada Gambar 3.

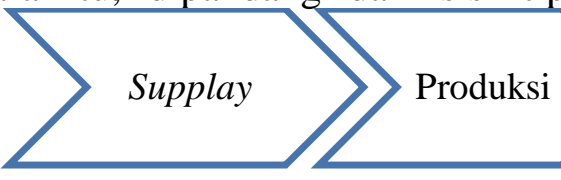

Pengendalian

Pengembangan

Gambar 3. Proses produksi

Sumber: Formulasi Teoritis oleh Peneliti

\section{Strategi Marketing}

Menurut Kotler \& Keller, terdapat delapan model komunikasi utama dalam marketing sebagai sebuah strategi, yaitu: periklanan, promosi penjualan, acara \& pengalaman, hubungan masyarakat \& publisitas, pemasaran langsung, pemasaran interaktif, pemasaran dari mulut ke mulut, dan

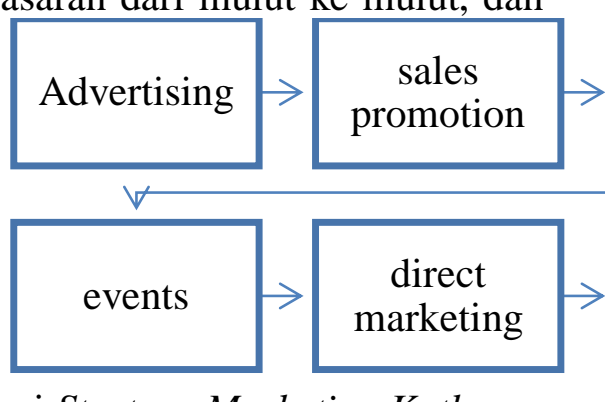

Gambar 4. Teori Strategy Marketing Kotler Sumber: Formulasi Teori Kotler oleh Peneliti

\section{METODOLOGI}

Penelitian ini menggunakan pendekatan kualitatif. Pendekatan ini dipilih karena penjualan pribadi. Hal ini juga dipertegas oleh Aditya bahwa terdapat lima strategi komunikasi marketing, yaitu periklanan, promosi penjualan, penjualan pribadi, hubungan masyarakat, dan pemasaran langsung (Aditya, 2015). Teori Kotler sebagaimana di kutip oleh Aditya ini dapat digambarkan pada Gambar 4.

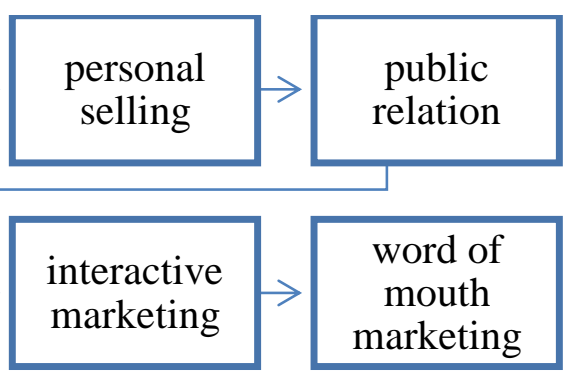

peneliti hendak melakukan eksplorasi mendalam, analisis dan menemukan kebaharuan (Novelty) tentang strategi atau langkah-langkah kongkrit tentang 
pengembangan SDM pesantrenpreneur, bentuk atau proses rantai pruduksi dan strategi marketing yang diterapkan. Studi tentang best practice ekosistem pesantrenpreneur ini menggunakan desain multikasus karena peneliti hendak memotret beberapa kasus sesuai dengan fokus dengan latar belakang yang berbeda.

Studi ini dilakukan di ponpes Ihya'ussunnah dan Madinatul Ulum. Dua pesantren ini sama-sama memiliki unit usaha yang dikelola oleh lembaga khusus. Ihya'ussunnah memiliki unit usaha produksi kopi BIKLA yang dikelolah oleh SMK Peratanian. Sementara Madinatul Ulum memiliki unit usaha peternakan ayam yang dikelola oleh bidang usaha pondok.

Terdapat dua jenis data yang hendak peneliti gali, yaitu data emik dan data etik. Data emik yang akan peneliti gali berupa gambar proses produksi, dokumen personalia dan catatan strategi pemasaran. Sementara data etik yang akan peneliti gali berkaitan dengan wawancara langsung dan observasi tentang kiat pengembangan SDM dan kiat marekting. Sementara itu, pengumpulan data dalam proses penelitian menggunakan wawancara mendalam/FGD, dokumentasi dan wawancara.

Sesuai dengan desain penelitian yang penelitih pilih, maka analisis data dalam penelitian menggunakan analisis data lintas kasus. Adapun langkah analisis yang akan peneliti lakukan adalah sebagai berikut: a) Memaparkan data sesuai dengan variabel dan fokus penelitian pada dua lokus, b) Menyandingkan data sesuai dengan fokus pada dua lokus, c) Mandialogkan data sesuai fokus dari dua lokus, d) Menemukan kebaharuan yang di abstraksi dari dua lokus sesuai dengan fokus.

Teknik analisis data lintas kasus ini di awali dengan proses analis kasus tunggal. Analisis data kasus tunggal ini menekankan pada analisa parsial dari masing-masing fokus penelitian pda setiap lokus. Langkah analisis lintas kasus ini dapat dilihat pada Gambar 5.

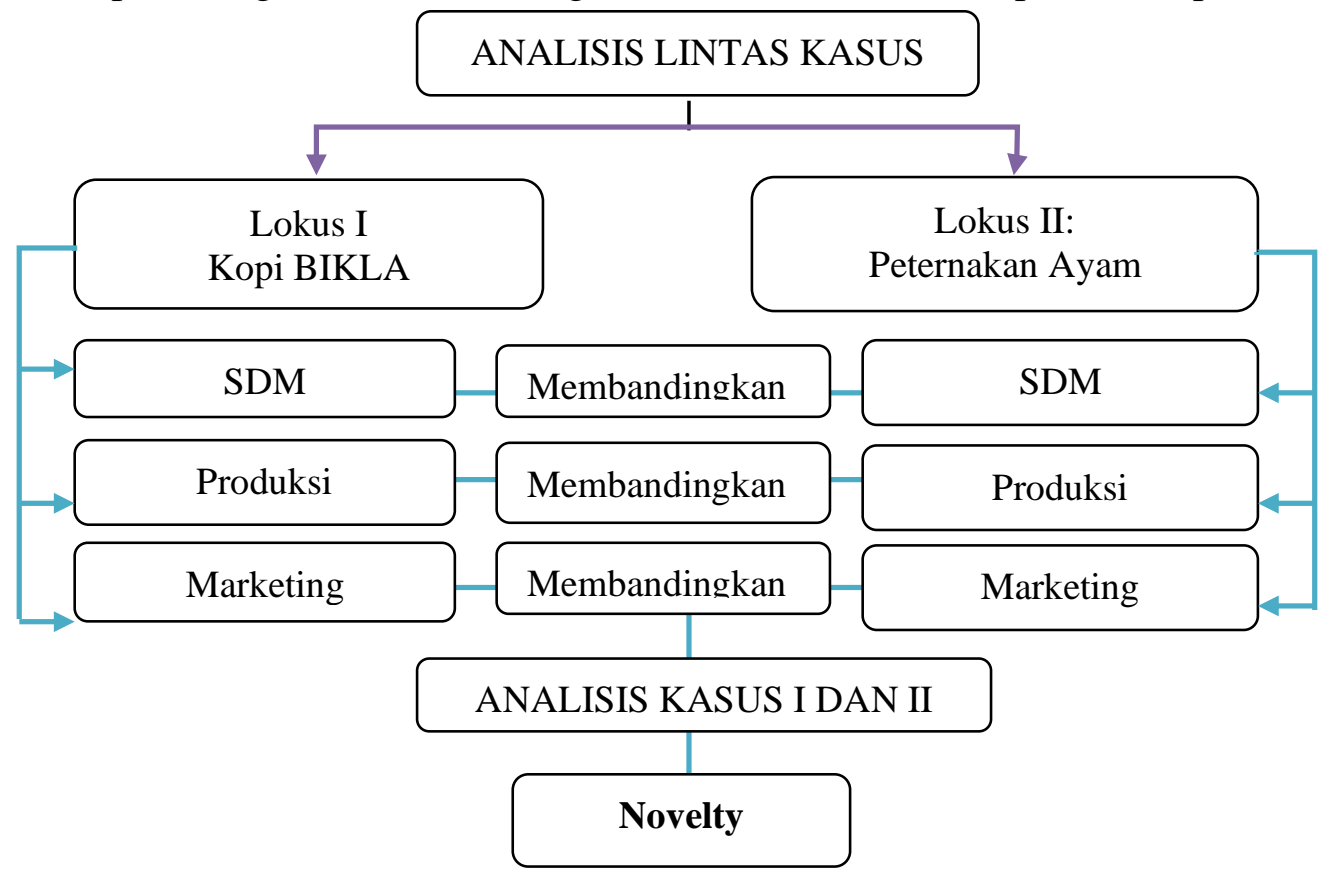

Gambar 5. Analisis lintas kasus

\section{HASIL DAN PEMBAHASAN}

\section{Sekilas tentang Pontren Ihya'ussunnah dan Madinatul Ulum}

Pesantren Ihya'ussunnah, Jember berdiri pada tahun 2002 dan diasuh oleh KH. Imam Bukhory, M. Pd. Pesantren ini terletak di dusun Canting, Desa Tugusari, Kecamatan Bangsalsari, Kabupaten Jember. Progtam pendidikan yang dikelola antara lain Madrasah Diniyah, MI Al Hasany, SMP Al Hasany, dan SMK Teknologi Pertanian Bangsalsari. Sumber daya alam Ponpes Ihya'ussunnah, ini adalah kopi seluas $50 \mathrm{Ha}$, Karena itulah selain belajar agama para santri juga diajari berkebun tujuan adalah para santri mempunyai kemampuan pengolahan kopi. 
Ponpes Madinatul Ulum dirintis oleh (alm) KH. Ahmad Sa'id pada Januari 1990 dan dibadan hukumkan oleh KH. Luthfi Ahmad pada tahun 2001 dengan akte notaris No. 08 Tanggal 05 Februari 2001 Soesanto Adi Poernomo, SH. Jember. Pesantren ini berlokasi di Jalan Tempurejo No. 20-24, Desa Cangkring Kecamatan Jenggawah Kabupaten Jember. Hingga saat ini ponpes Madinatul Ulum diasuh dan dipimpin oleh $\mathrm{KH}$. Luthfi Ahmad.

\section{Ekosistem Pesantrenpeneur}

Formulasi ekosistem pesantrenprenuer menghendaki adanya optimasi pada seluruh sistem dan elemen penting dalam dunia usaha. Memposisikan masing-masing elemen secara proporsional dan berkelindan. Kendatipun demikian, dalam wirausaha yang memiliki ruang lingkup dan skala yang lebih kecil, ekosistem ini dapat disederhanakan sesuai dengan core bussiness dalam sebuah unit usaha, seperti unit usaha yang berada di dalam dan dikelolah oleh ponpes, dikenal sebagai sebuah institusi atau lembaga pendidikan keagamaan yang memiliki keunikan dan kekhasan tersendiri.

Salah satu dari keunikan yang berada di ponpes adalah tentang ekosistem wirausaha yang dikembangkannya. Dengan bertumpu pada prinsip kemandirian dan pengembangan ekonomi umat, wirausaha ponpes menekankan pada tiga aspek pengembangan usaha, yaitu [1] Kapasitas SDM, [2] Proses dan manajemen produksi, dan [3] Strategi pemasaran yang digunakan. Tiga unsur penting inilah yang kemudian disebut sebagai "Ekosistem Pesantrenpreneur". Sebuah model pengembangan usaha berbasis ponpes. Gambaran ekosistem secara sederhana dapat dilihat pada Gambar 6 .

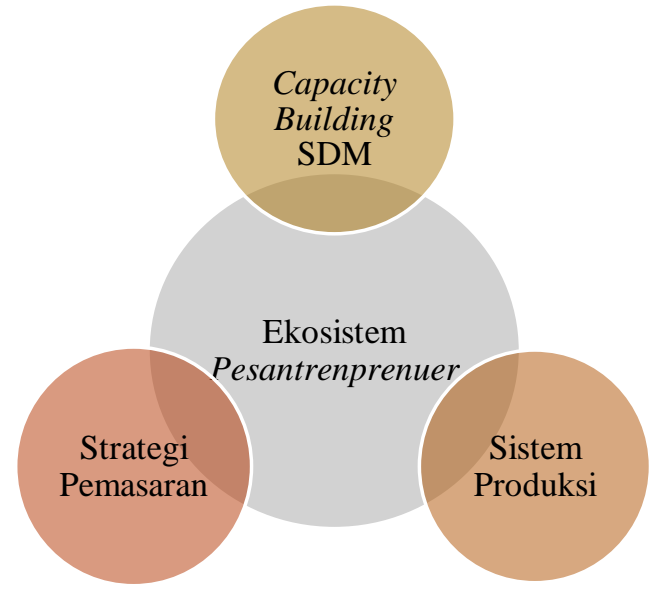

Gambar 6. Ekosistem pesantrenpeneur

Sumber: Formulasi Peneliti

\section{Desain Pengembangan Pesantrenprenuer}

Salah satu unsur penting dalam pengembangan pesantrenprenuer adalah sumber daya manusia (Aldo, 2017). Keberadannya menjadi penentu operating system lainnya. Keberhasilan dan suksesi usaha sangat ditentukan oleh kualitas sumber daya manusia yang dimiliki (Supriyadi, 2015). Inti dari kualitas sumber daya manusia tersebut berhubungan dengan: [1] Soft Skill, yaitu sebuah kemampuan dan daya pikat pribadi, mulai dari komitmen, motivasi dan nilai-nilai yang dianutnya. [2] Hard Skill, yaitu kemampuan dalam melakukan dan menginisiasi sebuah pekerjaan dan tugas yang dibebankan, seperti kemampuan manajerial dan kemampuan teknis (Untung, 2014). Khusus dalam konteks pengembangan SDM pesantrenprenuer, terdapat tiga komponen penting yang harus diperhatikan, yaitu:

\section{Value}

Tata nilai yang mengilhami perilaku masyarakat pesantren dalam pengembangan usaha meliputi: [1] Kekeluargaan, yaitu menjadikan semua SDM yang terlibat sebagai sebuah keluarga besar yang saling support, sharing skill dan berkompetisi secara sehat. [2] Gotong royong, yaitu perilaku positif komunitas usaha yang senantiasa melakukan 
kerjasama yang konstruktif. [3] Kemandirian, yaitu semangat atau optimisme proporsional yang senantiasa menganggap bahwa dirinya mampu dalam menjalankan tugas dan amanah. Mendahulukan prinsip melayani dari pada meminta dilayani.

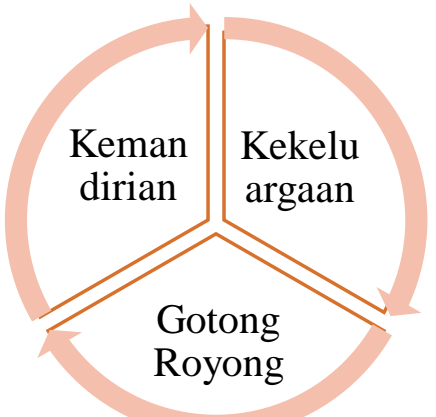

Gambar 7. Pesantrenprenuer values

Sumber: Elaborasi Teoritis Peneliti

\section{Proses Pengembangan SDM Pesantrenprenuer}

Kompetensi merupakan bagian penting dalam memilih dan menempatkan SDM pada unit usaha ponpes (Kristiana, 2018). Hal ini harus mampu dideteksi sebagai basis data dalam proses pengembangan sumber daya manusia. Dalam kontkes ini maka pengembangan sumber daya manusia pesantrenprenuer dapat dilakukan dengan langkah sebagai berikut: 1) Screening, yaitu sebuah cara dalam melakukan rekrutmen dan seleksi SDM yang akan terlibat dalam proses usaha pesantren. 2) Staffing, yaitu proses menempatkan sumber daya manusia yang telah disepakati melalui konsensus anggota yayasan. Capacity Building, yaitu langkah dalam upaya meningkatkan kemampuan dan proses penyesuaian lanjutan atas tugas-tugas yang telah dijalankan, dan 3) Evaluasi, yaitu proses atau analisa kinerja dan kontrol untuk perbaikan.

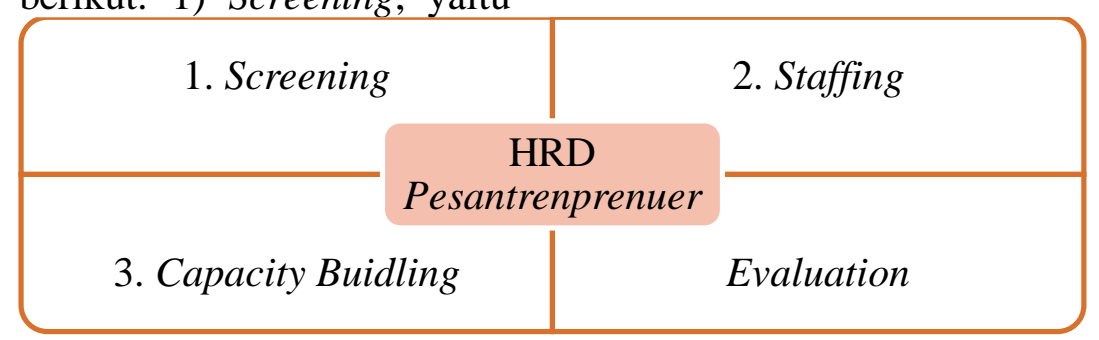

Gambar 8. HRD pesantrenprenuer Sumber: Elaborasi Teoritis Peneliti

\section{Support System}

Kebutuhan akan daya dukung tersebut secara sederhana meliputi: [1] Daya dukung Finansial, hal ini mencakup gaji standar dari reward kinerja dan capaian target. [2] Support

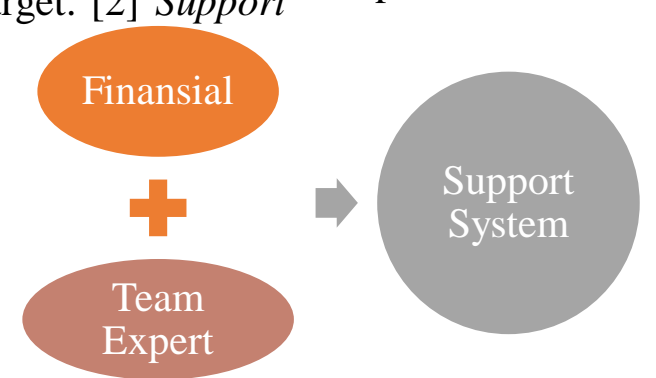

Gambar 9. Support system pesantrenprenuer

Sumber: Elaborasi Teoritis Peneliti

Team Expert, yaitu daya dukung dari tenaga ahli, baik ahli perencanaan, analisa pasar, keuangan dan pengendalian. Support System SDM pesantrenprenuer ini dapat digambarkan pada Gambar 9.

\section{Support}


Human Resourcs Develepment atau pengembangan sumber daya manusia pesantrenprenuer merupakan bagian pertama dalam ekosistem pesantrenprenuer. Ia berfungsi sebagai pilar terdepan dalam menjalankan sistem bisnis di ponpes. Selain menekankan pada desain sistem yang digunakan, HRD pesantrenprenuer ini menjadikan SDM lokal sebagai individu yang harus dilibatkan dan diberdayakan dalam proses bisnis. Sub-sistem yang menjadi bagian dari HRD pesantrenprenuer adalah [1] Nilai Local, [2] Proses Pengembangan SDM, dan [3] Support System. Sistem HRD Pesantren dapat digambarkan pada Gambar 10.

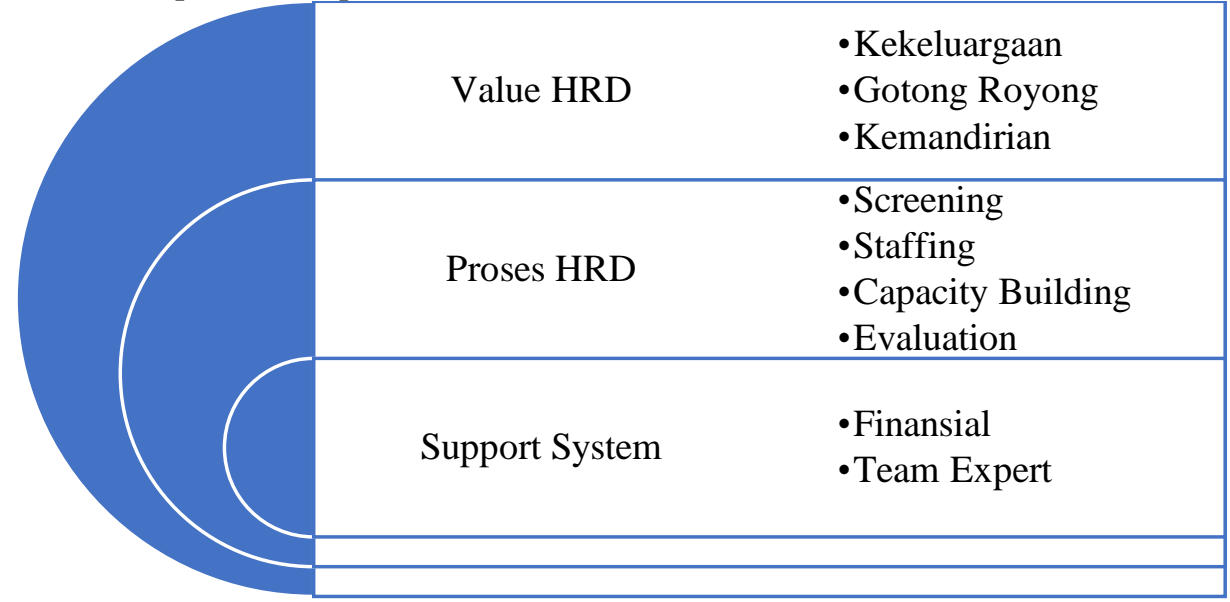

Gambar 10. Desain HRD pesantrenpreneur

\section{Desain Proses Produksi Pesantrenprenuer}

Produksi merupakan sebuah proses mencipatakan barang dan jasa untuk memeroleh benefit dan profit (nilai ekonomis), (Sickles, 2019). Dalam prosesnya, produksi tidak hanya berkaitan dengan pembuatan atau konstruksi nilai suatu barang, tetapi berhubungan rangkaian awal produksi hingga pengembangan dan pengendaliannya. Membuat atau memproduksi merupakan salah satu dari rangkaian dari proses produksi. Karena produksi tidak hanya menekankan pada terwujdunya sebuah barang dan jasa, tetapi harus menjamin feasibility, sustainability dan kebermanfaatannya (Hunger, 2003). Berdasar pada konsep ini, maka desain proses produksi pesantrenprenuer memiliki rangkaian atau siklus produksi sebagai berikut:

\section{Analisa Potensi}

Salah satu faktor penting yang harus dianalisis sebuah menjalankan dan memulai produksi, yaitu [1] Tingkat kebutuhan masyarakat terhadap barang dan jasa yang akan diproduksi (Need Assesment). [2] Daya jangkau terhadap bahan dasar produksi, mulai keterjangkauan lokasi, biaya dan kapasitanya. [3] Ketersediaan SDM yang akan menjalankan dan mengendalikan usaha. [4] Peluang bisnis yang mungkin didapat dan resiko bisnis yang mungkin dihadapi, dan [5] Analisis kompetitor, hal ini guna untuk memastikan posisi produk barang dan jasa yang akan diproduksi. Proses analisa usaha pesantrenprenuer ini dapat digambarkan pada Gambar 11.

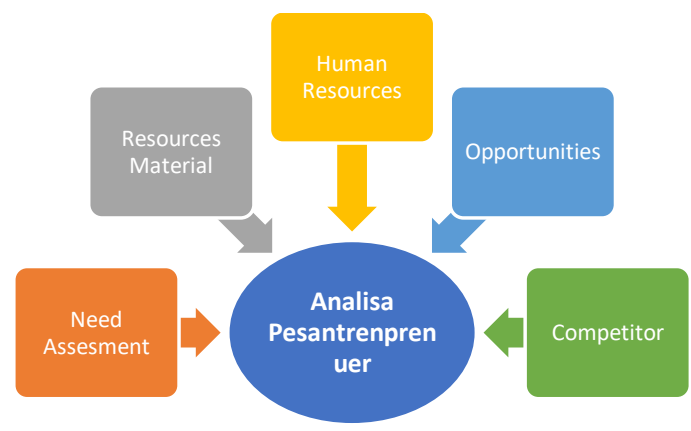

Gambar 11. Analisa pesantrenprenuer

Sumber: Elaborasi Teoritis Peneliti 


\section{Supplier}

Supplay berhubungan penyedia dan ketersediaan bahan baku dari barang dan jasa yang akan diproduksi. Idealnya, bahan baku produksi harus bersumber dari sumber daya
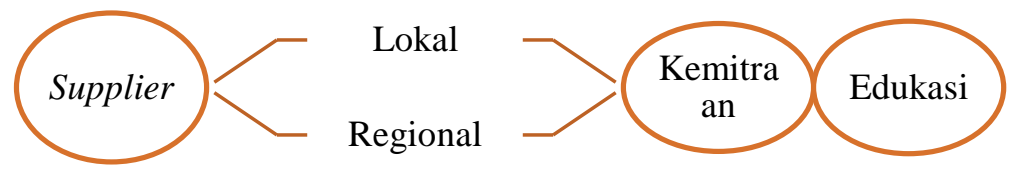

Gambar 12. Relasi supplier vs produsen pesantrenprenuer

Sumber: Elaborasi Teoritis Peneliti

\section{Produksi}

Bagian terpenting dalam rantai produksi adalah proses pembuatan dan menciptakan sebuah produk. Idealnya, proses produksi dilakukan berpijak pada mewujudkan kualitas produk dan faktor pembeda antara produk satu lokal yang melimpah. Keuntungan dari kategori bahan baku lokal ini adalah [1] Pemanfaatan sumber daya lokal, [2] Mengurangi cost transportation. Hal ini dapat digambarkan sebagai berikut:

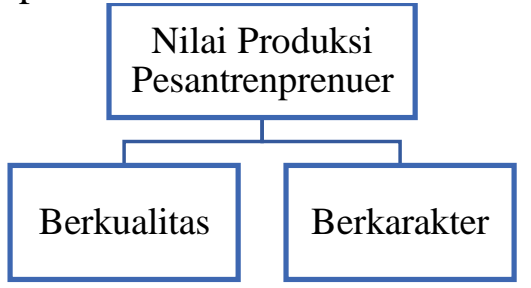

Gambar 13. Nilai produksi pesantrenprenuer Sumber: Elaborasi Teoritis Peneliti

\section{Inovasi dan Pengembangan}

Inovasi dan pengembangan merupakan upaya mencari nilai-nilai baru dalam sebuah produk (Nanang, 2017). Bentuk inovasi dan pengembangan produk yang menjadi langkah dengan produk lainnya (Kotler, 2005). faktor pembeda ini sekaligus akan menjadi kekhasan dan branding bagi produk yang dihasilkan. Proses produksi pesantrenprenuer ini dapat digambarkan pada Gambar 13.

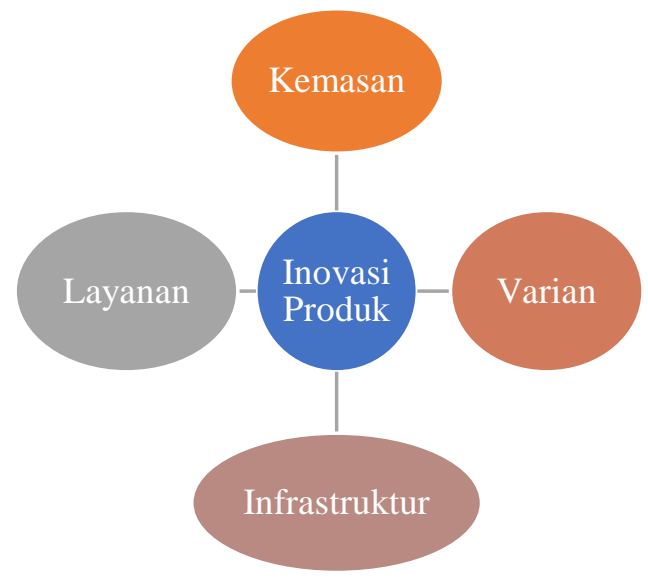

Gambar 14. Inovasi dan pengembangan produk Sumber: Elaborasi Teoritis Peneliti

\section{Pengendalian}

Pengendalian dalam proses ini merupakan sebuah aktivitas yang dilakukan untuk memastikan bahwa proses yang dan strategi pesantrenpreneur, meliputi: [1] Inovasi kemasan, [2] Inovasi varian produk, [3] Inovasi infrastruktur, dan [4] Inovasi Standar layanan. Inovasi dan pengembangan produk ini dapat digambarkan sebagai berikut:

Kemasan 
dan pasif. Dalam bentuk aktif, berarti membutuhkan keterlibatan SDM secara langsung dalam sistem kendali. Sementara pengendalian pasif bisa dilakukan dalam bentuk implementasi dan pengetatan pada standar operasional prosedur. SOP dikenal sebagai sistem kendali formal yang harus dijalankan oleh seluruh SDM dalam unit usaha. Termasuk dalam hal ini adalah SOP pengambilan keputusan yang berlaku di wilayah manajerial. Dua sistem kendali produksi ini dapat digambarkan pada Gambar 15 .

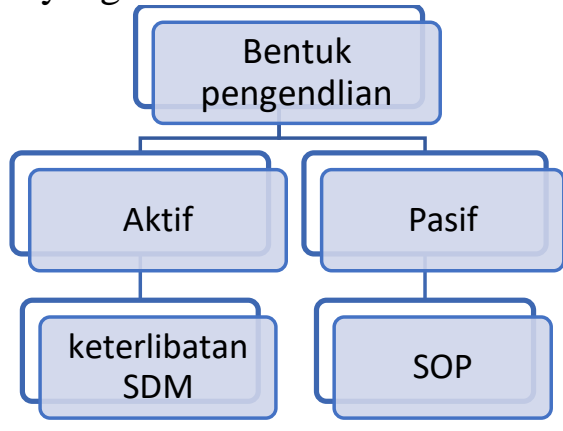

Gambar 15. Bentuk pengendalian pesantrenpreneur

Sumber: Elaborasi Teoritis Peneliti

Desain Proses produksi pesantrenpreneur merupakan cara dan pendekatan yang memadukan antara pure bussines dan social enterpreneurship. Menggabungkan antara kepentingan transaksional dengan kepentingan pemberdayaan sosial. Melalui imporovisasi

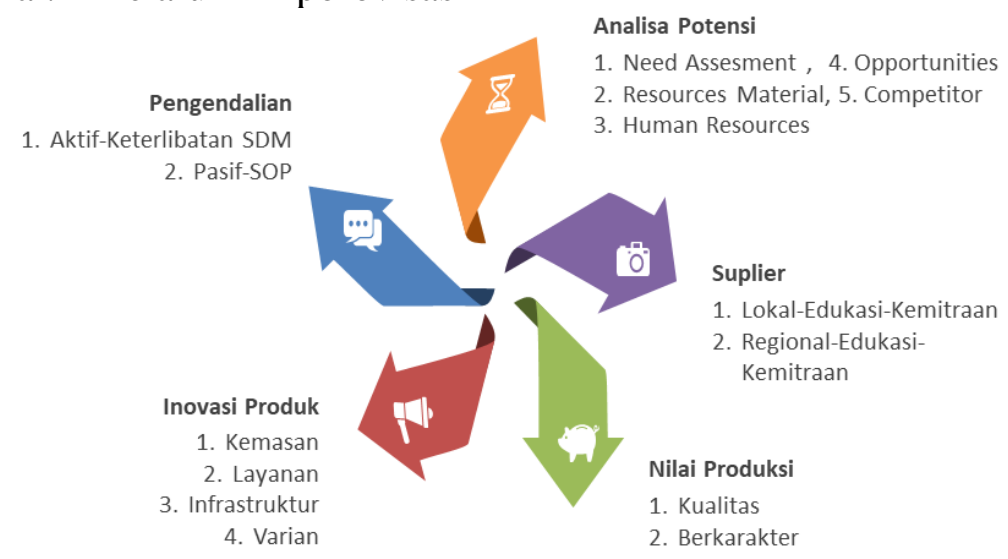

Gambar 16. Proses produksi pesantrenprenuer Sumber: Elaborasi Teoritis Peneliti

\section{Desain Strategi dan Pendekatan Marketing Pesantrenprenuer}

Pendekatan dan strategi pemasaran bagi sebuah produk sangat bergantung pada: [1] Jenis produk yang akan diperjual belikan, [2] Segmentasi konsumen, dan [3] Kanal pemasaran yang tersedia. Itulah sebabnya, secara teorites, pendekatan dan strategi pemasaran sangat beragam. Sehingga tidak ada strategi yang lebih baik dari pada yang lain untuk dipergunakan karena yang ada hanyalah strategi mana yang lebih tetap (Iffan, 2020). Namun demikian, desain strategi pemasaran pada berbagai sektor, seperti, pemberdayaan pada supplier, inovasi teknologi, sistem kendali dan pengembangan produk. Model proses produksi ini dapat digambarkan pada Gambar

16. 
yang akan dituju. Segmentasi ini berdasarkan: [1] Kuantitas kebutuhannya atas produk, [2] Lokasi atau wilayah antar, dan [3] Kompetitor, b) Even, yaitu sebuah strategi dalam mengenalkan dan mempromosikan barang, c) Media Sosial, yaitu sebuah strategi pemanfaatan kanal media sosial untuk melakukan promosi sekaligus penjualan langsung, dan d) Personal, yaitu sebuah strategi pemasaran yang secara langsung berhadapan dengan pembeli.

\section{Closed System Marketing}

Strategi pemasaran dengan sistem tertutup adalah pola pemasaran yang menyasar segmen tertentu dengan sistem member atau kontrak mitra. Salah satu keuntungan dari model ini adapat stabilitas permintaan. Strategi pemasaran tertutup yang menjadi salah satu model dari pemasaran pesantrenpreneur, yaitu 1) Multi Level Marketing, yaitu model pemasaran dengan mempersyaratkan keanggotaan dan berorientasi bonus/komisi, 2) Sistem Mitra, yaitu model pemasaran dengan cara menciptakan keterikatan antara penjual dan pembeli untuk membeli produk dan jasa yang dihasilkan. Sistem mitra ini dikenal dengan langganan.

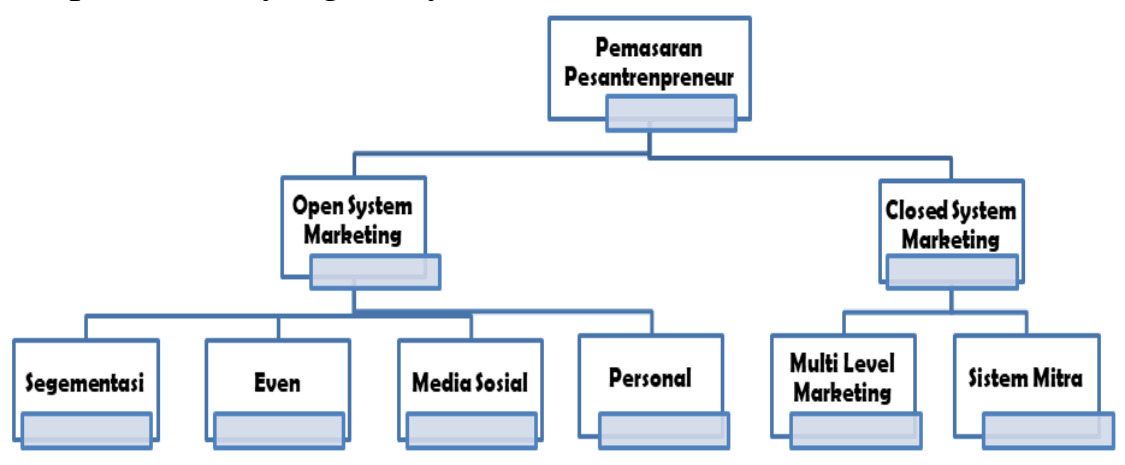

Gambar 17. Strategi marketing pesantrenpreneur Sumber: Elaborasi Teoritis Peneliti

\section{PENUTUP}

Berdasarkan problem research, topik, teori dan pembahasan yang telah peneliti uraikan, maka dapat disimpulkan sebagai berikut: Pertama, Strategi pengembangan sumber daya manusia (HRD) pesantrenprenuer berbasis pengembangan potensi lokal tiga komponen utama, yaitu [1] Berkaitan dengan internalisasi nilai, yaitu kekeluargaan, gotong royong dan kemandirian, [2] Proses HRD, meliputi Screening, Staffing, Capacity Building, dan Evaluation, dan [3] Support System yang terdiri dari support finansial dan team expert. Kedua, Proses produksi yang dilakukan oleh pesantrenprenuer berbasis pengembangan potensi lokal memiliki tahapan sebagai berikut, yaitu [1] Analisa potensi, yang terdiri dari Need Assesment, Resources material, Human resources, Opportunities, dan Competitor analysis. [2] Memilih Supplier, yang terdiri dari supplier lokal dan regional, [3] Nilai Produksi, dengan cara menjaga stabilitas kualitas produk dan menemukan deferensiasi produk. [4] Inovasi Produk, yang meliputi inovasi kemasan, varian, infrastruktur dan layanan, dan [5] Pengendalian, baik yang dilakukan secara aktif, dengan adanya keterlibatan SDM pengendali atau yang dilakukan secara pasif melalui implementasi SOP secara ketat. Ketiga, Pendekatan atau strategi marketing pesantrenprenuer berbasis pengembangan potensi lokal dilakukan dalam dua sistem, yaitu: [1] Open System Marketing, yang dapat dilakukan dengan cara melakukan segmentasi pasar, mengadakan event, melalui sosial media dan promosi atau penjualan langsung secara personal. [2] Closed System Marketing yang bisa dilakukan dalam bentuk MLM dan sistem kemitraan.

Saran dan rekomendasi implementatif dari penelitian ini ditujukan kepada para stakeholder untuk melakukan hal-hal berikut berikut, yaitu: [1] Membuat gerakan massif untuk pengembangan ekonomi ponpes secara serius dan berkelanjutan. [2] Menfasilitasi pengembangan SDM terampil dengan mendirikan lembaga DIKLAT di masingmasing ponpes sesuai dengan kebutuhan riil. 
[3] Membuat platform pemasaran produk yang dihasilkan oleh seluruh ponpes se-Indonesia.

\section{UCAPAN TERIMAKASIH}

Dalam prosesnya, penelitian ini telah banyak melibatkan berbagai kalangan. Dengan ini kami ucapkan terima kasih kepada: Pertama, Puslitbang Kementerian Agama RI yang telah menfasilitasi/ mendanai kami dalam melakukan penelitian, Kedua, PP Madinatul Ulum dan PP Ihya'ussunnah yang telah dengan koopratif dan memberikan kesempatan pada kami dalam melakukan penelitian, Ketiga, Para Informan, yang telah dengan antusias melayani dan memberikan informasi pada peneliti. Besar harapan, penelitian ini dapat bermanfaat untuk pengambilan kebijakan di lingkungan kementerian agama dan masyarakat pada umumnya.

\section{DAFTAR PUSTAKA}

Adhim, Fauzan (2020) Arah Baru Manajemen Pondok Pesantren. Malang: Literasi Nusantara

Bukit, Benjamin (2017) Pengembangan Sumber Daya Manusia. Yogayakarta: ZAHR Publishing

Bukhori, Imam (2020) Wawancara tentang Potensi Pertanian Kopi, pada tanggal 20 November

Colin, (t.t.) Entrepreneurial Ecosystems And Growth Oriented Entrepreneurship, Background paper prepared for the workshop organised by the OECD LEED Programme and the Dutch Ministry of Economic Affairs on, The Hague, Netherlands,

Churiyah, Madziyatul (2015) Model Pembelajaran Kewirausahaan Sosial, Berbasis Potensi Lokal. Malang: Surya Pena Gemilang,

Depertemen Komunikasi Bank Indonesia, (2018) Tiga Program Kemandirian Ekonomi Pesantren untuk Mendukung Ekonomi Indonesia. di Post oleh BI pada tanggal 11 November tersedia pada www.bi.go.id, (Di Akses : 20 Nopember 2020)
Fattah, Nanang (2016) Manajemen Stratejik Berbasis Nilai. Bandung: Remaja Rosdakarya

Haratua, Armando dan Wijaya, Chandra (2020) 'Membangun Ekosistem Kewirausahaan untuk Usaha Mikro dan Kecil Di Indonesia: Sebuah Tinjauan Literatur', Jurnal Ilmu Administrasi Negara, Volume 16, Nomor 1, juli

Hidayat, Dayat \& Syahid, Ahmad (2019) 'Local Potential Development (Local Genius) in Community Empowerment', Journal of Nonformal Education Vol: 5, NO. 1

Hunger, J. David \& L. Wheelen, Thomas (2003) Manajemen Strategis. Yogyakarta: Andi Yogyakarta

Iffan, Muhammad (2020) Marketing Approach on Competitive Advantage of OnlineBased Public Transportation, Advances in Economics, Business and Management Reseach, volume 112

Hadi, Nafik (2018) 'Islamic Bording School Role in Social-Economic Empowerment in East Java in 20 Century', Jurnal Mozaik Humaniora, Vol. 18-2,

Kotler, Philip (2005) Strategi Marketing. Jakarta: PT. Salemba Empat

Mahzumi, Fikri (2017) Nahdlatut Tujjar Meneropong NU-Kapital, Al Fikr 101

Peregrino de Brito, Renata (2016) 'The Relationship Between Human Resource Management and Organizational Performance', Journal BBR, Vitória, Vol 13, Nomor. 3,

Redho Syam, Aldo and Arifin, Syamsul (2017) Manajemen Sumber Daya Manusia Pendidikan Islam Pendidikan Islam Di Era Globalisasi', JAL-ASASIYYA: Journal Basic Of Education 02, no. 01

R., Sickles \& Zelenyuk (2019) Measurement of Productivity and Efficiency: Theory and Practice. Cambridge: Cambridge University Press,

R. David, Fred \& R. David, Forest (2017) Manajemen Strategik, Jakarta: Salemba Empat 
Soleh, Ahmad (2017) 'Strategi Pengembangan Potensi Desa', Jurnal Sungkai, Vol.5 No.1

Suryo Bowo, Damar (2018) 'Analisis Perbaikan Proses Produksi Pada Pt Sumber Teknik Sentosa', Jurnal Manajemen Bisnis, volume 8 no. 01

Sri Utami, Kristiana (2018) 'Human Resources Competence and Performance Analisys of Batik Crafters at Pendowoharjo Batik Center', Jurnal EBBANK, Vol.9, No.2

Supriyadi, (2015) Manajemen Sumber Daya Manusia. Yogyakarta, CV. Andi Offset,
Tim

Penyusun

(2019)

Model

Pesantrenpreneurship

Berbasis

Koperasi. Surabaya: Dinas Koperasi JATIM dan OPOP Training Center UNUSA,

Untung Manara, M. (2014) 'Hard Skills dan Soft Skills pada Bagian Sumber Daya Manusia di Organisasi Industri', Jurnal Psikologi Tabularasa, Volume 9, NO.1

Wardhana, Aditya (2015) 'Marketing Strategies and Their Impact on Marketing Performance of Indonesian Ship Classification Society', International Journal of Science and Research (IJSR) ISSN (Online): 23197064, Volume 4 Issue 2. 